\title{
Quinazoline derivatives: synthesis and bioactivities
}

\author{
Dan Wang and Feng Gao*
}

\begin{abstract}
Owing to the significant biological activities, quinazoline derivatives have drawn more and more attention in the synthesis and bioactivities research. This review summarizes the recent advances in the synthesis and biological activities investigations of quinazoline derivatives. According to the main method the authors adopted in their research design, those synthetic methods were divided into five main classifications, including Aza-reaction, Microwave-assisted reaction, Metal-mediated reaction, Ultrasound-promoted reaction and Phase-transfer catalysis reaction. The biological activities of the synthesized quinazoline derivatives also are discussed.
\end{abstract}

Keywords: Quinazoline derivative, Synthesis, Bioactivity

\section{Introduction}

Quinazoline derivatives, which belong to the N-containing heterocyclic compounds, have caused universal concerns due to their widely and distinct biopharmaceutical activities. Researchers have already determined many therapeutic activities of quinazoline derivatives, including anti-cancer [1-4], anti-inflammation [5,6], anti-bacterial [7-10], analgesia [5,9], anti-virus [11], anti-cytotoxin [12], anti-spasm $[9,13]$, anti-tuberculosis [14], anti-oxidation [15], antimalarial [16], anti-hypertension [17], anti-obesity [18], anti-psychotic [19], anti-diabetes [20], etc. Medicinal chemists synthesized a variety of quinazoline compounds with different biological activities by installing various active groups to the quinazoline moiety using developing synthetic methods. And the potential applications of the quinazoline derivatives in fields of biology, pesticides and medicine have also been explored. This review summarized the representative synthetic methods, either traditional or novel, and categorized them into five main classifications, including Aza-reaction, Microwave-assisted reaction, Metal-catalyzed reaction, Ultrasound-promoted reaction and Phase-transfer catalysis. Besides, three other kinds of reactions were also listed out, which were either designed as supplementary methods in most experiments or used as the main methods in some researches,

\footnotetext{
* Correspondence: gaofeng@sicau.edu.cn

Department of Chinese Traditional Herbal, Agronomy College, Sichuan

Agricultural University, No. 211, Huiming Road, Wenjiang Region, Chengdu 611130, P. R. China
}

(c) 2013 Wang and Gao; licensee Chemistry Central Ltd. This is an Open Access article distributed under the terms of the Creative Commons Attribution License (http://creativecommons.org/licenses/by/2.0), which permits unrestricted use, distribution, and reproduction in any medium, provided the original work is properly cited.

\section{Review}

\section{Synthetic methods}

Aza-reaction

Aza-Diels-Alder reaction Imino-Diels-Alder reaction [21] containing the coupling of imine and electron-rich alkene gradually became a powerful tool for the synthesis of quinazoline derivatives [22]. In Povarov imino-DielsAlder reaction, aniline and ethyl glyoxalate were chosen as substrates. And two molecules of $\alpha$-iminoesters, which were got from the condensation of aniline and ethyl glyoxalate, were hypothesized to form the direct additive product. Cascade Imino-Diels-Alder reaction conducted by Chen et al. [23] was extended from the Povarov IminoDiels-Alder reaction. In this research, researchers chosed the same substrates as in the Povarov Imino-Diels-Alder reaction, and adopted various kinds of Lewis acid as catalysts, then the reagents were refluxed in toluene for one day, and finally produced quinazoline derivatives $3 . \mathrm{CuBr}_{2}$ was determined as the optimized catalyst with highest yields (Scheme 1). 


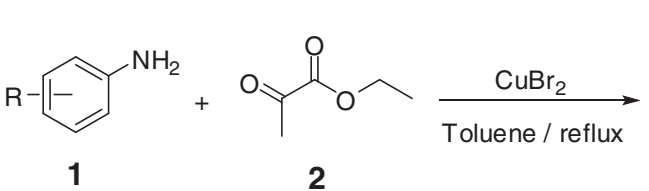

2

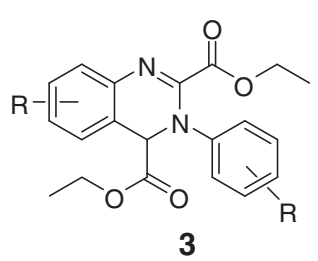

3

Scheme 1 Synthesis of derivatives 3 by cascade imino-Diels-Alder reaction.

Aza-Wittig reaction Aza-Wittig reaction, which generally precedes in cascade with easy operation under mild reaction conditions, is widely used in the synthesis of $\mathrm{N}$ heterocycles [24]. He et al. reported a kind of tandem Staudinger-Aza-Wittig-Nucleophilic addition reaction to synthesize indolo[1,2-c]quinazolines recently [25]. The main synthetic procedure of this research was using azides 4 and triphenylphosphine to react in toluene for $2 \mathrm{~h}$ at room temperature, and then heating at reflux for 6-24 h. Results showed that the nitrogen evolution through the Staudinger reaction halted during the initial $2 \mathrm{~h}$, and surprisingly produced the final product indolo[1,2- c] quinazolines 6 directly from the reaction mixture (Scheme 2).A synthetic method for 2-alkoxy$3 \mathrm{H}$-quinazolin-4-ones was reported by Ding et al. in 2004 [26]. In this study, twelve novel 2-alkoxy-3Hquinazolin-4-ones were synthesized from carbodiimide 8, which was obtained from aza-Wittig reaction of iminophosphorane 7 with aromatic isocynate (Scheme 3). Sophie Barthelemy et al. applied perfluoroalkyl-tagged triphenylphosphine in a fluorous biphasic system for the synthesis of $3 \mathrm{H}$-quinazolin-4-ones by aza-Wittig reaction [27]. Compounds such as Type 11 were adopted as substrates to react quantitatively with per fluoro-tagged phosphine 12 to obtain iminophosphoranes 13 . Then these intermediates converted directly into the desired quinazoline derivatives through intramolecular aza-Wittig reaction. The reactions were preceded in toluene as solvent and trifluorotoluene as co-solvent (Scheme 4). After the reaction, desired products 15 were separated through solid-extraction on fluorous reversed-phase silica gel, for that the unreacted iminophosphoranes 13 and phosphane oxide 14 would leave the perfluoro tag on silica gel, thus make the products be washed off effectively. In this way, it was made possible for simple segregation of quinazolin-4-ones even with unquantitative cyclization reaction.

\section{Microwave-assisted synthesis}

Compared to traditional heating methods, microwave heating could expand reaction range as well as shorten the reaction time from a few days or hours to a few<smiles>[R1]NC(=O)C(c1ccccc1N=P)N(C([R])=O)c1ccccc1C(C(N)=O)N(C([R])=O)c1ccccc1N=P</smiles>

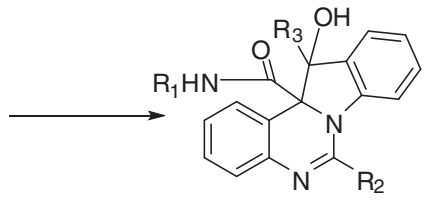

6

Scheme 2 Synthesis of indolo[1,2-c]quinazolines 6 from azides 4 .

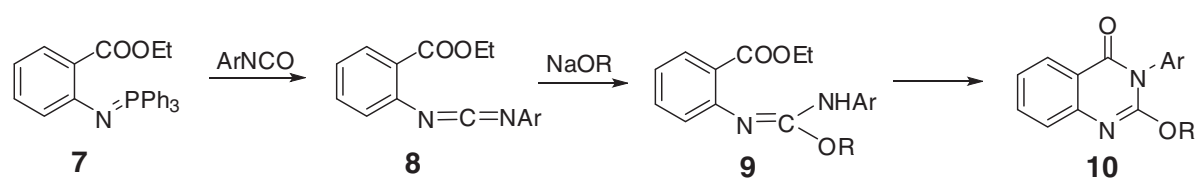

Scheme 3 Synthesis of 2-alkoxy-3H-quinazolin-4-ones. 


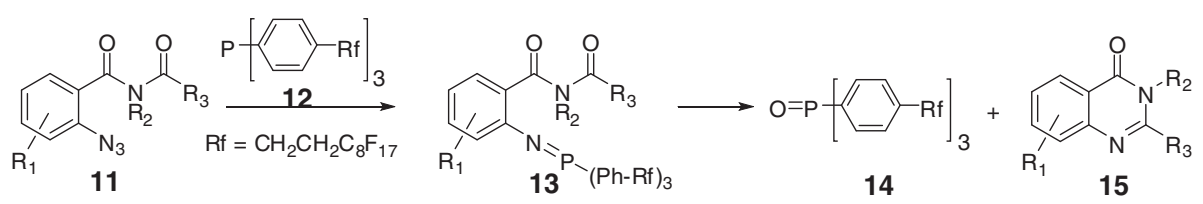

Scheme 4 Synthesis of 3H-quinazolin-4-ones via aza-Wittig reaction.

minutes. Thus, when applied in fields of organic synthesis, pharmaceutical chemistry and high-throughput chemistry, microwave heating shows greater advantage than traditional heating methods [28-31].

Luo et al. reported the first microwave-assisted synthesis of new quinazoline derivates containing $\alpha$ aminophosphonate [32]. In their method, N'-(substituted2-cyanophenyl)-N,N-dimethyl-formamidine derivatives and dialkyl amino (phenyl) were adopted as the raw materials to react in 4:1 volume ratio of isopropanol to acetic acid solvent for $20 \mathrm{~min}$ under microwave irradiation $\left(100^{\circ} \mathrm{C}\right.$, $100 \mathrm{psi}$ ), and obtained twenty-four quinazoline compounds 18, two of which had similar activity as commercial reagent Ningnanmycin (Scheme 5).

Tu et al. reported a fast, one-pot, microwave-assisted synthesis of polysubstituent imidazo[1,2-a]quinoline, pyrimido [1,2-a]quinoline and quinolino[1,2-a]quinazoline derivatives [33]. They explored the optimal reagent, volume and heating temperature by testing different reagents under different reaction time and temperature. Then under the optimal conditions $\left(2.0 \mathrm{~mL}\right.$ glycol and $\left.120^{\circ} \mathrm{C}\right)$,several aldehydes were separately reacted with various enaminones and malononitrile to obtain different products (Scheme 6).
In the synthetic research conducted by Kidwai et al. [34], the target compounds quinazoline derivatives 28 were obtained by heating an equimolar amount of aldehyde 25, 5,5-dimethyl-1,3-cyclohexanedione (dimedone) 26 and urea/thiourea 27 under microwave irradiation in the absence of solvent and catalyst (Scheme 7).

Hazarkhani et al. adopted isatoic anhydride and 2aminobenzimi-dazole as the raw materials, DMAC as solvent in their starting research and got 2-amino- $\mathrm{N}-(1-\mathrm{H}$ benzimidazol-2-yl) benzamide under microwave irradiation [35]. Then they discovered that this novel amide has three nucleophilic sites to condense with different electrophilic compounds, which made it applicable for the synthesis of numerous quinazolinone based targets, and was applied in the following synthesis.

Amides (5 mmol), triethylorthoformate $(7.5 \mathrm{mmol}), \mathrm{p}$ tolue-nesulfonic acid $(0.25 \mathrm{mmol})$ and DMAC $(1-2 \mathrm{ml})$ were mixed in a tall beaker covered with stem-less funnel, and heated for $4 \mathrm{~min}$ under $600 \mathrm{w}$ microwave power in a microwave oven, then interrupted in between with a cooling procedure. After that, the reaction mixture was cooled to room temperature and poured into a large volume of water for precipitation. Then the precipitate was

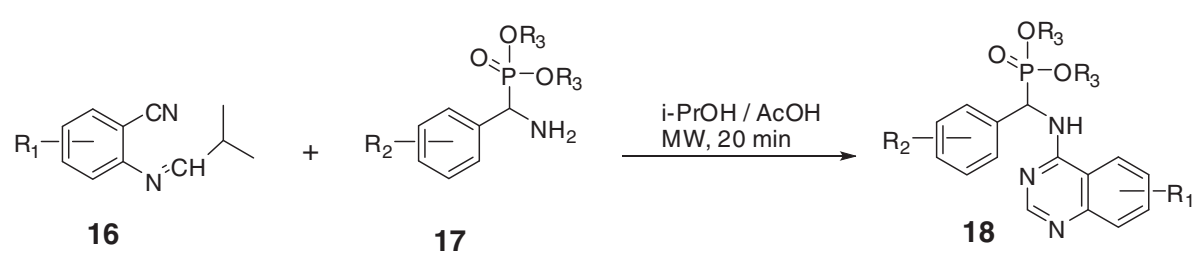

Scheme 5 Synthesis of quinazoline compounds containing a-aminophosphonat.<smiles></smiles><smiles>[R]c1ccc(C(=O)O)c(NC2=CCC(C)(C)CC2=O)c1</smiles>

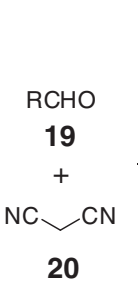

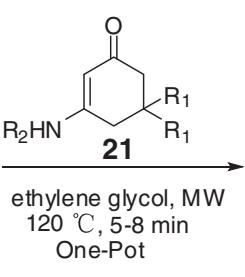<smiles>[R]C1C2=C(CC([R])([R])CC2=O)N2NC(=O)CC(C#N)=C2C1[R]</smiles>

22

Scheme 6 Microwave-assisted one-pot synthesis of quinazoline compounds. 


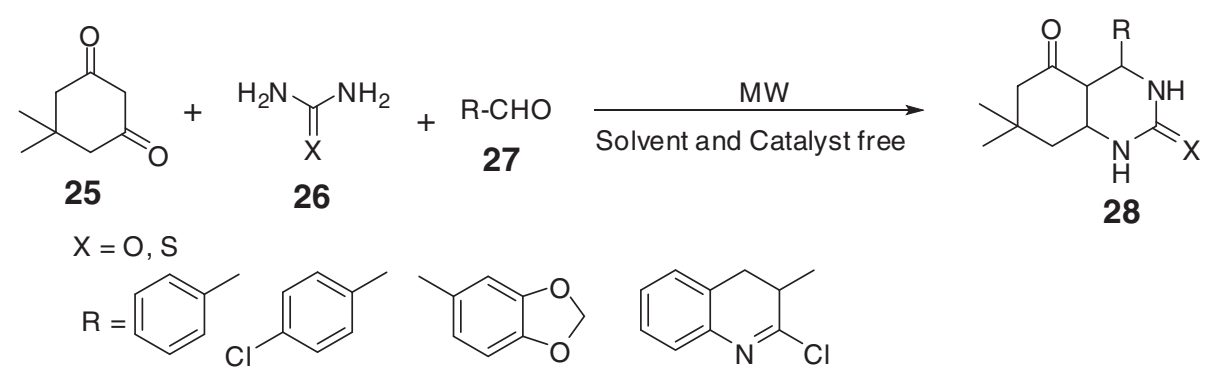

Scheme 7 Solvent-catalyst-free microwave-assisted synthesis of quinazolines.

filtered and recrystallized with $95 \%$ ethanol to obtain pure product 3-benzimidazolyl-4(3H)-quinazolinone (31) with a yield of $94 \%$ (Scheme 8 ).

\section{Metal-mediated reaction}

\section{Palladium-catalyzed reaction}

Palladium-catalyzed coupling reaction, which plays a vital role in the pharmaceutical industry, is widely applied in chemical synthesis industry and laboratories as an efficient method for the formation of $\mathrm{C}-\mathrm{C}$ and $\mathrm{C}$-heteroatom bond.

Qiu et al. determined the optimum conditions for the palladium-catalyzed three-component synthesis of quinazolino[3,2-a]quinazolines as follows: amine (3.0 equiv), isocyanide (3.0 equiv), carbodiimide $(0.2 \mathrm{mmol}), \mathrm{Pd}(\mathrm{OAc})_{2}$ (5 mol\%) and $\mathrm{Cs}_{2} \mathrm{CO}_{3}$ (3.0 equiv) in $3.0 \mathrm{ml}$ toluene (Scheme 9) [36].

McGowan et al. developed a palladium-catalyzed onepot synthesis of quinazoline derivatives [37]. The reaction process was shown in Scheme 10.

Zinc-reduced synthesis Zinc is the first capable metal found to participate in water-phase Barbier reaction. It could catalyze the allylation of carbonyl and carbonyl compounds as well as participate in the benzylation of carbonyl and some special alkylation. Apart from participating in the carbon-oxygen double bond Barbier reaction, Zinc could also be applied to carbon-nitrogen double bond Barbier reaction, such as the allylation of imine and $\alpha$-amino aldehyde. In short, Zinc could stably exist in water phase with relatively strong activity. Active zinc obtained from ultrasonic-electrical method could even improve the reaction efficiency by more than three times. Although it often causes a few side effects, the cost-effectiveness and low-toxicity of zinc made it a good catalyst for organic reduction and synthetic reaction. In the synthetic research of imidazo[1,2-c]quinazoline derivatives designed by Shi et al. [38], 2-(2-nitrophenyl)- $1 \mathrm{H}$-imidazoles 39 was reduced by $\mathrm{Zn} / \mathrm{H}^{+}$to 2 (2-aminop henyl)-1H-imidazoles 40 , which then reacted with isothiocyanates to get intermediate 41. Cylization of compound 41 by nucleophilic attack of the nitrogen atoms on $\mathrm{C}=\mathrm{S}$ group was afford the intermediates 42 . Finally, the desired products 43 were obtained from 42 by losing of $\mathrm{H}_{2} \mathrm{~S}$ (Scheme 11). Low-valent titanium reagents, which aroused an increasing concern in the field of organic synthesis, could effectively improve the

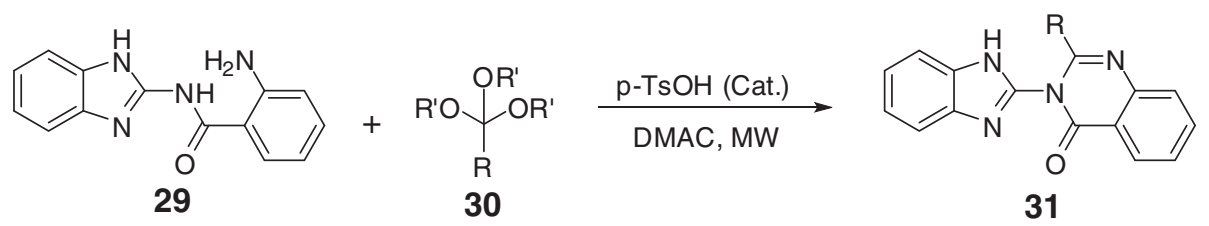

Scheme 8 Synthesis of 3-benzimidazolyl-4(3H)-quinazolinones.

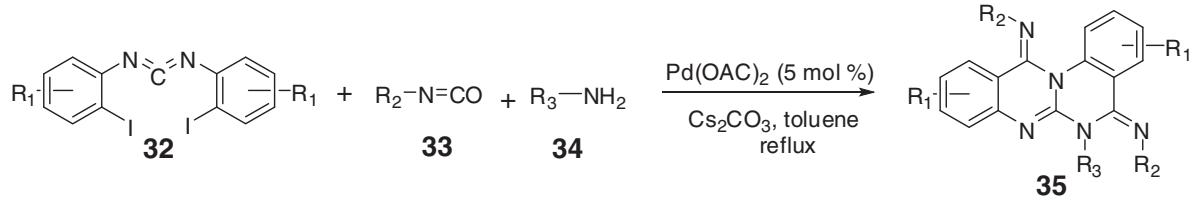

Scheme 9 Synthesis of quinazolino[3,2-a]quinazolines. 


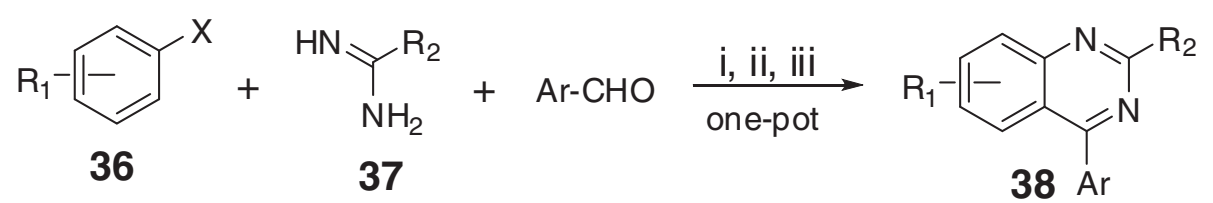

Scheme 10 Palladium-catalyzed one-pot synthesis of quinazolines.

coupling of carbonyl compounds [39]. A synthetic method assisted by low-valent titanium reagent was reported by the same group mentioned above [40]. In this synthesis, a series of quinazoline derivatives were afforded by adopting anhydrous THF as solvent and the $\mathrm{TiCl}_{4}$ - $\mathrm{Zn}$ system as reducing agent. Several representative synthetic routes were selected, which were shown in Scheme 12.

Copper-catalyzed reaction Aryl ether, alkyl ether, aryl amine, alkyl amine, aryl sulfide, alkyl sulfide, etc., which are all very important structural fragments in many<smiles>O=[N+]([O-])c1ccccc1-c1nc(Br)c(Br)[nH]1</smiles>

39<smiles>Nc1ccccc1-c1nc([Al])c([Al])[nH]1</smiles>

40

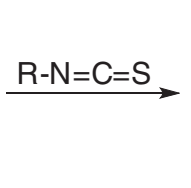<smiles>[R]NC(=S)Nc1ccccc1-c1nc(Br)c(Br)[nH]1</smiles><smiles>[17N]c1nc2ccccc2c2nc(Br)c(Br)n12</smiles>

43

Scheme 11 Synthesis of imidazo[1,2-c]quinazoline derivatives.<smiles>[R]c1ccc([N+](=O)[O-])c(CN[Al])c1</smiles>

44<smiles>[Y7]c1cc(-c2nc([Al])c([Al])[nH]2)c([N+](=O)[O-])cc1[Y7]</smiles>

47<smiles>[R]c1ccc([N+](=O)[O-])c(C(N)=O)c1</smiles>

50<smiles></smiles>

42

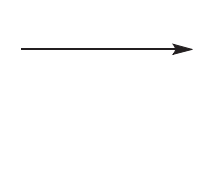$$
\text { . }
$$ 


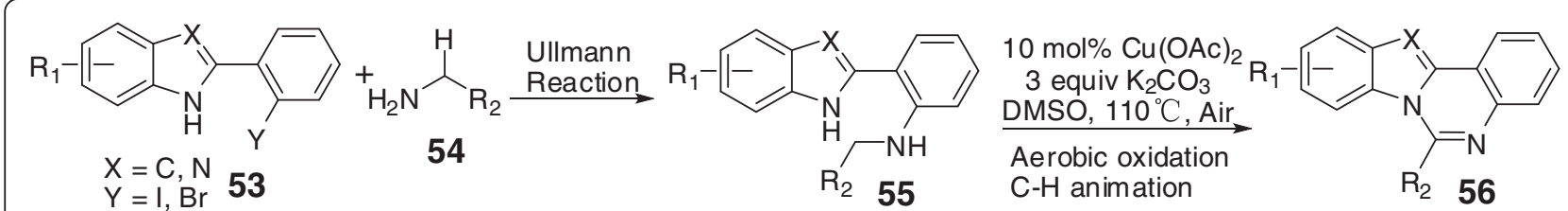

Scheme 13 Copper-catalyzed synthesis of indolo[1,2-c]quinazoline derivatives.

chemical molecules, have an urgent need for better synthetic methods. Classical copper-catalyzed Ullmann reaction has been widely studied due to its significant role in this regard. It raised attention from many chemists and became one of the focal point in organic chemistry research in recent years. Sang et al. reported a coppercatalyzed sequential Ullmann $\mathrm{N}$-arylation and aerobic oxidative $\mathrm{C}-\mathrm{H}$ amination for the convenient synthesis of indolo[1,2-c]quinazoline derivatives [41]. In their research, 2-(2-halophenyl)-1H-indoles and (aryl)methanamines were adopted as raw materials to generate corresponding Schiff base via Ullmann reaction. Then gas as oxidant, 3 equiv $\mathrm{K}_{2} \mathrm{CO}_{3}$ as base, DMSO as solvent and $10 \mathrm{~mol} \% \mathrm{Cu}(\mathrm{OAc})_{2}$ as catalyst were revealed as the optimum conditions, to conduct aerobic oxidative $\mathrm{C}-\mathrm{H}$ amination under $110^{\circ} \mathrm{C}$ (Scheme 13).Jiang et al. also reported a copper-catalyzed one-pot synthesis of 5,12-dihydroindolo[2,1-b]quinazolines [42]. The best conditions of catalyst, ligand, base and solvent were determined as $10 \mathrm{~mol} \%$ of CuI, $20 \mathrm{~mol} \%$ of trans-4-hydroxyl-L-proline, 3.0 equiv of $\mathrm{K}_{2} \mathrm{CO}_{3}$, DMSO and $90^{\circ} \mathrm{C}$, respectively. $\mathrm{N}$-(2-bromobenzyl)-2-iodoani-line (57) and malononitrile (58) were adopted as the raw materials to afford desired compound 59 through coppercatalyzed intramolecular C-N coupling reaction (Scheme 14).

A two-step catalytic synthesis of 2-substituted-1,2,3,4tetrahydroquinazolinones was investigated by Kundu et al. [43], including the palladium-copper co-catalyzed $\mathrm{C}$-arylation of terminal alkynes and copper-catalyzed cyclization of disubstituted alkynes. First of all, 2-(N-Alkyl-N-prop-2' -ynyl)amino-N'-p-tosyl benzamides and aryl iodides were adopted as the raw materials to react in presence of 5 equiv of $\mathrm{Et}_{3} \mathrm{~N}$ for $16 \mathrm{~h}$, catalyzed by $2.5 \mathrm{~mol} \%\left(\mathrm{Ph}_{3} \mathrm{P}\right)_{2} \mathrm{PhCl}_{2}$ and $5 \mathrm{~mol} \% \mathrm{CuI}$, to generate a series of disubstituted alkynes. Then the products were cyclized in the presence of $\mathrm{CuI}(30 \mathrm{~mol} \%), \mathrm{K}_{2} \mathrm{CO}_{3}(2.5$ equiv) and $\mathrm{Bu}_{4} \mathrm{NBr}$ (1 equiv) at $80^{\circ} \mathrm{C}$ for $16-24 \mathrm{~h}$ in $\mathrm{CH}_{3} \mathrm{CN}$ to afford the desired products 1-methyl(benzyl)-(E)-2(2-arylvinyl)-3-p-tosyl-1,2,3,4-tetrahydroquinazoline-4-ones with high yield. The structures of obtained compounds were shown in Figure 1.

\section{Ultrasound-promoted synthesis}

In critical synthesis, ultrasonic assistance is needed to meet the high requirements for temperature and pressure. For instance, in Bischler cyclization [44-46], the most traditional synthetic methods for quinazoline derivatives, high temperature (above $120^{\circ} \mathrm{C}$ ) and high pressure are needed for at least $5 \mathrm{~h}$ in saturated ammonia alcohol solution. Various synthesis applying this method contains the passage of ammonia through a mixed melt of the amino compound and sodium acetate at a temperature higher than $160^{\circ} \mathrm{C}$ [47], in which ultrasonic promotion is demanded.

Zhang et al. reported an ultrasound-assisted synthesis of novel quinazoline derivatives, including a four-step synthesis of quinazoline core and the optimization of the Bischler cyclization [48]. The optimum reagents and conditions of the four steps were as follows: (a) iron powder(reductant), concentrated $\mathrm{HCl}$ (catalyst), ethanol/ water(co-solvents with $\mathrm{V}: \mathrm{V}$ of 5:1), $50^{\circ} \mathrm{C}$; (b) 4-nitrobenzoic acid chloride( 1 equiv), TEA(1.2 equiv), DCM, $0^{\circ} \mathrm{C}$; (c) $25 \%$ ammonia water, water, ultrasound $250 \mathrm{~W}, 80^{\circ} \mathrm{C}, 3 \mathrm{~h}$; (d) iron powder, concentrated $\mathrm{HCl}$, ethanol/water, $50^{\circ} \mathrm{C}$ (Scheme 15).

\section{Phase-transfer catalysis}

Phase-transfer catalysis (PTC) is considered to be one of the promising methods in organic synthesis of specialty chemicals. The previous 20 years sees a steady increment in articles and patents dealing with PTC topics and their applications. Currently, rather than be simply used in replacement reactions, PTC is widely applied in
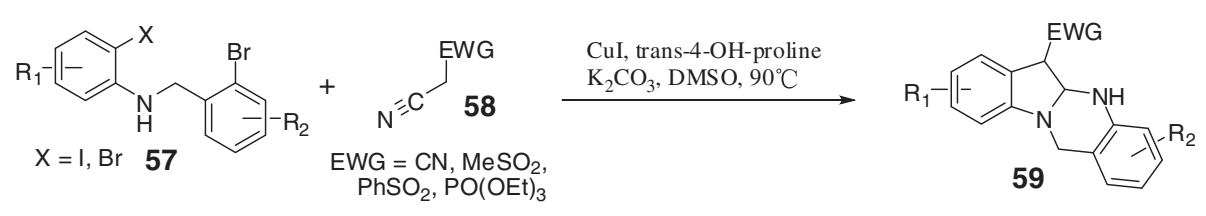

Scheme 14 Copper-catalyzed one-pot synthesis of quinazolines derivatives. 


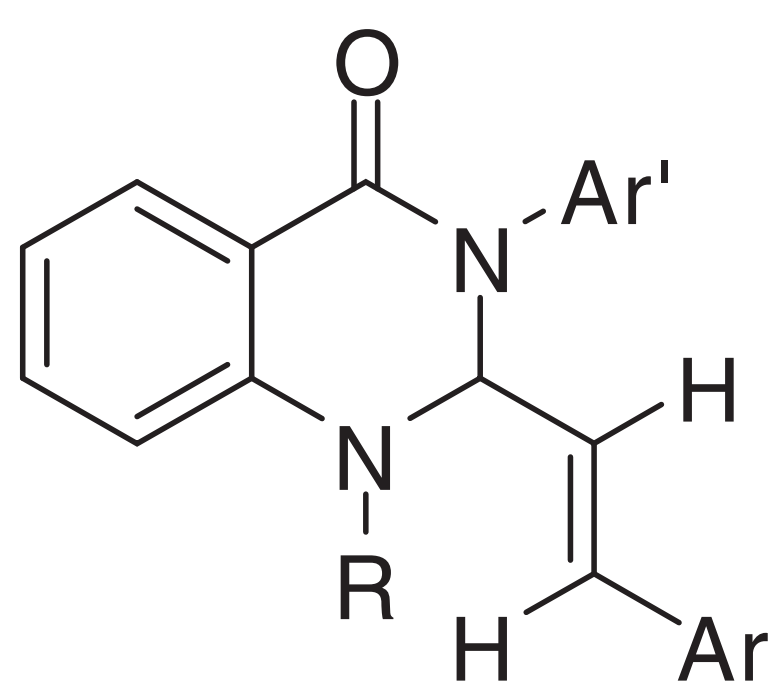

Figure 1 Structures of palladium-copper co-catalyzed synthesis of quinazolines.

polymer chemistry, heterocyclic chemistry, organometallic synthesis, agrochemicals, dyes, flavors, spices, and pharmaceutical technology [49-51].

In the synthetic research conducted by A. Kh. Khalil [52], the optimum conditions were determined as follows: Dioxane/anhydrous potasstium carbonate be set as liquid/solid phases and TBAB be set as catalyst. The 2-mercaptoquinazolin-4(3H)-one (65) was stirred effectively with haloorganic reagents under optimal conditions at $25^{\circ} \mathrm{C}$ for $2-4 \mathrm{~h}$. Then in the following tests, compound 65 was treated respectively with ethyl bromide, allyl bromide, bromoactylacetone, and diethyl malonate bromide by molar ratio of 1:3, and afforded a series of quinazoline derivatives via S-monoalkylation. While treatments with several other compounds, including methyl iodide, benzyl bromide, $\omega$-bromo-4-methoxyacetophenone, ethyl bromoacetate, and chloroacetyl chloride could afford products 66 via a simultaneous S- and N-dialkylation (Scheme 16).

Yao et al. designed an investigation to bring bromine into the active structure of quinazoline sulfide [53]. Anthranilic acid was adopted as the starting material to generate a series of 6-bromo-4-alkylthioquinazoline compounds 74 via phase-transfer catalysis through a sequence of reaction, including acylation, bromination, hydrolysis, ring formation, vulcanization and thioether substitution (Scheme 17).

Apart from the five synthetic methods listed above, several other methods could also be used as main researching methods in some situation, while most of the time, they were set as auxiliary methods or necessary methods in experimental design. Here, several examples of such methods were listed.

\section{Oxidative cyclization}

A three-step synthesis of mono- and bis-indolo[1,2-c] quinazolines was reported by Rohini et al. in 2010 [7]. In this research, the key indole precursor A was got from Fischer indole cyclization. And the corresponding intermediate mono and bis-2-(o-arylidineaminophenyl) indole, obtained from indole precursor $\mathrm{A}$, then was put on oxidative cyclization with powdered $\mathrm{KMnO}_{4}$ in acetone to afford the desired products mono and bis-indolo [1,2-c]quinazoline.

In 2009, they also reported another synthesis of monoand bis-6-arylbenzimidazo[1,2-c]quinazolines from corresponding 2-O-arylideneaminophenylbenzimidazoles by oxidative cyclization [54].

\section{Reagent refluxing}

Chandrika et al. synthesized desired products from the intermediate obtained from reagent refluxing [12]. In the synthesis of tri-substituted products triazolo[4,3-a]quinazolin-7-ones by Pandey et al. [55], the corresponding Schiff base was obtained from refluxing of key intermediate with isatin in methanol, which then cyclodehydrated to the products in concentrated sulfuric acid. Aside from these two researches, in some other synthetic researches $[5,34,56]$, the intermediates or products were also obtained from refluxing of raw materials or intermediates in solvent.

\section{One-pot synthesis}

In order to make the synthetic methods more convenient, many researchers gradually tend to integrate one-pot synthesis into their synthesis investigations. Such as<smiles>[R]C(=O)c1ccccc1N(CC(C)(C)C)C(=O)c1ccc([N+](=O)[O-])cc1</smiles>

Scheme 15 Ultrasound-assisted four-step synthesis of novel quinazoline derivatives. 
<smiles>O=c1[nH]c(S)nc2ccccc12</smiles>

65

\section{$\mathrm{RX}, \mathrm{TBAB}, \mathrm{RT}$ $\mathrm{K}_{2} \mathrm{CO}_{3} /$ Dioxan}<smiles>[R]Sc1nc2ccccc2c(=O)n1[R]</smiles>

66

Scheme 16 PTC synthesis of alkylation quinazoline derivatives.

microwave-assisted synthesis reported by Tu et al. [33], Copper-catalyzed domino synthesis reported by Jiang et al. [42], Palladium-catalyzed reaction reported by McGowan et al. [37] and Zinc-reduced synthesis reported by Shi et al. [38]. All of these reported methods were combined with one-pot synthesis.

\section{Bioactivity research}

\section{4-position substituted quinazoline compounds}

Melanin-concentrating hormone receptor 1 antagonists MCHR1 antagonising quinazoline derivatives are proved to possess distinct anti-obesity activity. Sasmal et al. investigated the potential anti-obesity activity of quinazoline derivatives, which were determined as MCHR1 antagonists [18]. A series of compounds were obtained by the change of substituent groups, including 4-propyl-quinazolinone, 4pyrrolidin-quinazolinone, 4-hydroxypiperidine-quinazoline, 4-pyrrolidin-quinazoline, 4-morpholinyl-quinazoline, etc. Firstly, the metabolic stability in blood and solubility of these compounds were studied. Then, their anti-obesity properties were tested. 4-Morpholinyl-quinazoline (75, Figure 2) showed good oral PK profile and was chosen as a prototype molecule used to test its effect in DIO C57BL/6 J mice. And the tested mice reached an obvious weight reduction of $12 \%$ in the fourteenth day, by oral administration of that compound ( $30 \mathrm{mg} / \mathrm{kg}$, b.i.d.). The results showed, the representative compound 4-morpholinylquinazoline owned an obvious anti-obesity activity. However, it was also pointed out that the compound was in need of further improvement of stability in plasma related to the oxymethylene linker.Besides, there are a number of other quinazoline derivatives that also possess good inhibitory activity for MCHR1, including 4-amino-2-cyclohexyl aminoquinazoline, 4-dimethylamino quinazoline, etc. Among these compounds, which work as MCHR1 antagonists, some $\mathrm{N}$-substituted amino quinazoline compounds exhibit high $\mathrm{IC}_{50}$ values due to their good affinity for human MCHR1, including ATC0065 and ATC0175 [57-59].

\section{Epidermal growth factor receptor tyrosine kinase inhibitors}

Researches suggest that EGFR tyrosine kinase inhibiting quinazoline derivatives possess significant anti-cancer activity. 4-Anilinoquinazoline showed a potent and highly selective inhibition for EGFR tyrosine kinase through ATP-competitive binding mechanism [60-66]. And quinazoline derivatives with aliphatic branch at 4position of quinazoline core have moderate inhibitory activity for cyclin-dependent kinase [67].

Chandregowda et al. synthesized novel 4-anilinoquinazolines and evaluated their anti-cancer activity [1]. The new results indicated that quinazoline derivatives with alkylthiobenzothiazole side chain in 6-position and electron withdrawing group substituted in 4-aniline contain better biological activities.

Lately, synthesis and activity research on 4anilinoquinazolines as well as extended researches on inhibitory activity of anilinoquinazolines for EGFR are reported continuously [68].For example, $\mathrm{Hu}$ et al. designed and synthesized several crown ether fused anilinoquinazoline analogues, combined with EGFR kinase in vitro test and EGFR mediated intracellular phosphorylation test [69]. $\mathrm{IC}_{50}$ values of these compounds range from $2 \mathrm{nM}$ to $150 \mathrm{nM}$. The results<smiles>CCOC(=O)COC(=O)c1ccccc1NC(=O)c1ccccc1C(=O)O</smiles>

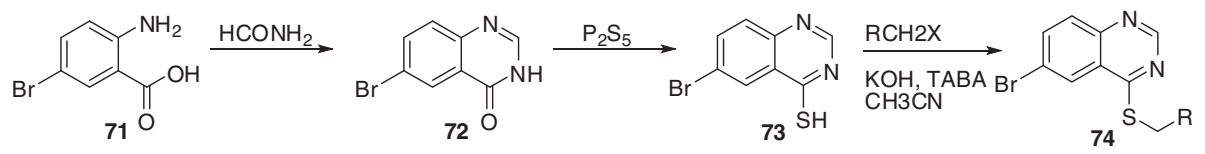

Scheme 17 PTC synthesis of 4-alkylthio-quinazoline derivatives. 
<smiles>Cc1nc(N2CCC(N3CCOCC3)CC2)nc2ccc(NC(=O)COc3ccc(OC(F)(F)F)cc3)cc12</smiles>

75<smiles>O=C(Nc1ccc(P)cc1)N1CCN(c2ncnc3ccccc23)CC1</smiles>

$77 \mathrm{R}=\mathrm{NO}_{2} \quad 78 \mathrm{R}=\mathrm{Cl}$

$79 \mathrm{R}=\mathrm{Br} \quad 80 \mathrm{R}=\mathrm{O}^{\mathrm{i}} \mathrm{Pr}$<smiles></smiles>

76<smiles>C(=N/Oc1ncnc2ccccc12)\c1ccc2c(c1)OCO2</smiles>

81

Figure 2 Structures of representative 4-substituted quinazolines with bioactivity.

indicated that substituent of ethynyl at meta-position or halogen on the 7-anilino were desirable for high potency. And among the products, compound 76 (Figure 2) expressed high resistance for EGFR and potent selectivity for kinases Abl and Arg, and showed good pharmacokinetic properties in preclinical evaluation. Moreover, it inhibited the growth of many human solid tumor xenografts in a dose-dependent way(range $50-100 \mathrm{mg} / \mathrm{kg}$ ).

Acrolein amine quinazolines substituted on the 6position could irreversibly bind with intracellular ATP binding domain of EGFR [70,71]. 6-Substituted-4-anilino quinazolines with irreversible binding property with EGFR were synthesized by Vasdev et al., starting from $\left[{ }^{18} \mathrm{~F}\right]$ fluoroanilines [3].

There are some other researches aiming at replacing 4-anilino with other substituents [72-74], such as thiosemicarbazide, which possesses a variety of biological profiles, including anti-cancer, anti-fungi, anti-bacterial, anti-inflammation and anti-virus. Thus it acts as an efficient pharmacophore in drug design. In order to find novel quinazoline compounds with same enzyme sites as 4-anilinoquinazoline, a series of 4-thiosemicarbazide quinazolines were synthesized by $\mathrm{He}$ et al. [75], and their anti-cancer activities were estimated using 5 human cancer cell lines with 5-FU as reference. Preliminary results showed that some produced compounds exhibited better inhibitory activity against these 5 human cancer cell lines than 5-FU. Structure-activity relationship results indicated that compounds with unsubstituted quinazoline ring and benzene ring or chloro/fluoro substituted benzene ring were proved to have higher anti-cancer activity.

\section{Platelet-derived growth factor receptor phosphorylation} inhibitors

Cell proliferation induced by unusual platelet-derived growth factor receptor (PDGFR) will lead to a variety of proliferative diseases such as atherosclerosis, restenosis following PTCA, glomerulonephritis, glomerulosclerosis, liver cirrhosis, pulmonary fibrosis, and cancer [76-86]. PDGFR phosphorylation inhibitors are potential treatments for these proliferative diseases [87].

Matsuno et al. obtained a series of compounds containing 4-piperazinyl substituted quinazoline core from screening of PDGFR phosphorylation inhibitors [87]. KN1022 was adopted as the prototype inhibitor in structure-activity relationship analysis, and the 4nitrobenzene urea moiety was studied, which indicated that compounds with substitution on 4-position of benzene ring worked best, but activity would be reduced with more than two substituents on benzene ring. In their research, several KN1022 (77) (Figure 2) derivatives with favorable activity were obtained, including 4-(4-methylphenoxy)phenyl,4-tert-butylphenyl and 4phenoxyphenyl. In vivo assays were conducted by oral administration of these three compounds $(30 \mathrm{mg} / \mathrm{kg}$, twice daily) to SD rats. 4-chlorophenyl (78), 4-bromophenyl (79), and 4-isopropoxyphenyl (80) (Figure 2) analogues were then proved to have obvious inhibitory activity against neointima formation in the carotid artery of the balloon catheter de-endothelialized vessel in the rats.

\section{Germicide}

Li et al. synthesized and biologically evaluated a series of 4-quinazoline oxime ether compounds in purpose of 
discovering novel acaricides [11]. Compounds obtained in this research were proved to have different degrees of suppression for phytovirus TMV, among which compound 81 (Figure 2) showed potent in vivo and in vitro activity against TMV, $65 \%$ and $61 \%$ respectively. What's more, bioassays showed that compound 81 also exhibited favorable inhibitory activities against CMV,PVX and PVY after virus vaccination.

\section{Heterocyclic quinazoline derivatives}

Imidazo-quinazolines In the synthesis of mono and bis-6-arylbenzimidazo[1,2-c]quinazolines by Rohini et al. [54], bioassays were conducted applying standard drugs Ampicillin and Ketoconazole as references. Among the products, the MIC of compound 82 (Figure 3) against Staphylococcus aureus, bacillus subtilis, streptococcus pneumoniae, Salmonella typhimurium, escherichia coli, klebsiella pneumoniae, aspergillus niger, candida albicans and Trichoderma viridae were $2.5,10,5,5,2.5,5,2.5$, 2.5, $5 \mu \mathrm{g} / \mathrm{mL}$ respectively.Rewcastle et al. synthesized several fused tricyclic quinazoline analogues and investigated their enzyme inhibitory activity [88]. Linear imidazo[4,5-g]quinazoline (83) was proved to be the most potent compound with an inhibition $\mathrm{IC}_{50}$ of $0.008 \mathrm{nM}$, and the N-methyl analog (84) showed similar activity as compound 83 (Figure 3). In the imidazo[4,5-g] quinazoline and pyrroloquinazoline series, the angular isomers showed much weaker inhibitory ability than the linear compounds, which was consistent with the results of the previous structure-activity relationship. Meanwhile, small electron-donating substituent at the 6- or (and) 7-positions was beneficial to the inhibitory activity.

Acylhydrazone quinazolines Acylhydrazone is a pharmacophore armed with favorable activity of antibiosis, anticancer and antivirus. Panneerselvam et al. synthesized several acylhydrazone quinazolines via condensation reaction of 3-amino-6, 8-dibromo-2-phenylquinazolin-4(3H)-ones and aromatic aldehyde [13]. Among which, the representative compound 85 (Figure 3) showed the most significant activity against $S$. aureus, $S$. epidermidi, M. luteus, B. cereus, E. coli, P. aeruginosa, K. pneumoniae, $A$. niger and $A$. fumigatus.

Triazole quinazolines Triazole quinazolines aroused attention for their various bioactivities. Baba et al. conducted anti-inflammatory research on quinazoline

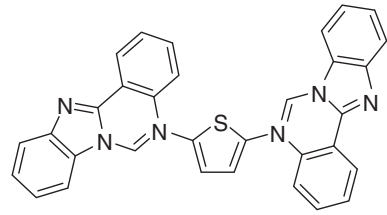

82<smiles>[R]c1[X]c(-c2ccc(OC)c(OC)c2)c2cc(OC)c(OC)cc2n1</smiles><smiles>[X]C#CC(=O)OCC</smiles><smiles>[X]C(=O)OCC</smiles>

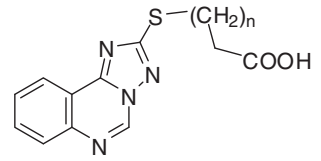

$90 n=0$

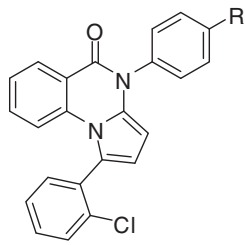

$92 \mathrm{R}=\mathrm{OCH}_{3}$ $93 \mathrm{R}=\mathrm{Cl}$<smiles>COc1ccc(/C=N/n2cnc3c(Br)cc(Br)cc3c2=O)c(OC)c1OC</smiles>

85<smiles></smiles>

89<smiles>O=c1c2ccccc2n2c3nc4ccccc4c-3nnc2n1-c1ccc(Cl)cc1</smiles>

94

Figure 3 Structures of representative heterocyclic quinazoline derivatives. 
derivatives [6]. Justicidins, the potent bone resorption inhibitors, were adopted as lead compounds, and quinazoline derivative 86 was discovered to show favorable anti-inflammatory effect on rats with adjuvant arthritis. Then the structure of compound 86 was modified by adding heteroaryl moiety on the alkyl side chain at 2position of the skeleton, result of which showed that installation of an imidazole or a triazole moiety on the 2-alkyl side chain could increase the anti-inflammatory. Then, compound 86 with $\mathrm{ED}_{50}$ of $2.6 \mathrm{mg} / \mathrm{kg} /$ day was selected as candidate for further research, which showed that the inhibitory ability against Th1 cytokine production of 87 was considered to be its significant immune regulating function (Figure 3).Fifteen [1,2,4] triazole [4,3-c] quinazoline derivates were synthesized and evaluated for their antimicrobial activity by Jantova et al. [89], among which, compound 88 (Figure 3) was found with the highest potency against Bacillus subtilis, Staphylococcus aureus, Candida tropicalis and Rick-ettsia nigricans. Nasr et al. evaluated the antimicrobial activity of novel 1,2,4-triazolo[4,3-c]-quinazoline analogues against typical gram-positive bacterium and Gram-negative bacterium [90]. Among these analogues, tetracyclic compound 89 showed higher activity than the reference drug of ciprofloxacin (Figure 3).Besides, 2-thio-[1,2,4]triazolo[1,5-c] quinazolinones with $\mathrm{C}-5$ substituted by sulfo-alkyl groups were discovered with moderate antimicrobial activity [91-93]. Based on the former researches, Antipenko et al. synthesized novel 2-thio-[1,2,4] triazolo [1,5-c]quinazoline derivatives and investigated their bioactivities [8]. Escherichia coli, Pseudomonas aeruginosa, Aspergillus niger, Mycobacterium luteum, Candida albicans and Candida tenuis were applied in the antimicrobial test, which showed that compounds 90 and 91 exhibited obvious suppression for Candida albicans, which was validated by further bioluminescence inhibition test and related to their lipophilicity (Figure 3).Pandey et al. also conducted antimicrobial researches on novel quinazolinones fused with [1,2,4]-triazole, [1,2,4]-triazine and $[1,2,4,5]$-tetrazine rings [55]. Among the quinazolinones derivates, compounds 92, 93 and 94 (Figure 3) showed excellent activities against Escherichia coli, pseudomonas aeruginosa, streptococcus pneumoniae, and bacillus subtilis.

\section{Other quinazoline analogues}

2,3-Disubstituted quinazolines 2,3-Disubstituted quinazolin-4(3H)-ones have been discovered with favorable analgesic and anti-inflammatory function $[94,95]$. Alagarsamy et al. reported several 2,3-disubstituted quinazoline analogues with potent analgesic and anti-inflammatory activity, such as 2-phenyl-3-substituted quinazolines [96], 2-methyl3-substituted quinazolines [97], 2-methylthio-3-substituted quinazolines [98] and 2,3-disubstituted quinazolines [99]. On the basis of these researches, they synthesized novel 3-phenyl -2-substituted-3H-quinazoline-4-ones in purpose of further reducing the ulceration side effects [5]. And the analgesic, anti-inflammatory and ulcerogenic index activities of these compounds were tested. Among the synthesized derivates, compounds 95, 96 and 97 (Figure 4) showed moderate analgesic activity. It is worth to mention that compound 97 exhibited higher anti-inflammatory potency, reference to standard drug of diclofenac sodium. In addition, the evaluated compounds all caused milder ulceration side effects, reference to aspirin.

Indole-involved quinazolines Indole moiety involved heterocycles are proved to have a wide variety of pharmaceutical and medical profiles, such as anti-inflammation, anti-microbial, anti-cancer, anti-malarial, etc. [100-106]. Rohini et al. conducted anti-microbial study on the newly produced 6-substituted indolo[1,2-c] quinazolines applying gram-positive bacterium (Staphylococcus aureus, Bacillus subtilis and Streptococcus pyogenes), gram-negative<smiles>[R]C([R])=NNc1nc2ccccc2c(=O)n1-c1ccccc1</smiles><smiles>[X]c1ccc2nc(C)nc(NCCCCC)c2c1</smiles>

$$
\begin{aligned}
& 95 \mathrm{R}_{1}=\mathrm{CH}_{3}, \mathrm{R}_{2}=\mathrm{CH}_{2} \mathrm{CH}_{3} \\
& 96 \mathrm{R}_{1}=\mathrm{CH}_{2} \mathrm{CH}_{3}, \mathrm{R}_{2}=\mathrm{CH}_{2} \mathrm{CH}_{3} \\
& 97 \mathrm{R}_{1}=\mathrm{CH}_{3}, \mathrm{R}_{2}=\mathrm{CH}_{2} \mathrm{CH}_{2} \mathrm{CH}_{3}
\end{aligned}
$$

Figure 4 Structures of representative other quinazoline analogues. 
bacterium (Salmonella typhimurium, Escherichia coli and Klebsiella pneumonia), and pathogenic fungus (Aspergillus niger, Candida albicans and Trichoderma viridae) as the test bacterium, and standard drug ampicillin and ketoconazole as reference, which indicated that some of the synthesized compounds showed favorable inhibition against the tested microorganism [7].

2,4,6-trisubstituted quinazolines Chandrika et al. synthesized and biologically evaluated various 2,4,6-trisubstituted quinazoline derivatives. The core of compound 98 (Figure 4) showed antimicrobial activities against gram-positive bacterium and gram-negative bacterium. In addition, it could be drawn from the SAR that decylamine group substituted at C-4 is beneficial to the activity while iodo-group at C-6 is detrimental to activity [12].

\section{Conclusions}

Traditional synthetic methods for quinazoline derivatives, still in general use, including Aza-synthetic method, refluxing, oxidative cyclization, are fundamental methods for the synthesis of this important heterocyclic compounds. It could be seen from the examples compiled above that some novel synthetic methods are in constant development, and different methods are adopted in the synthesis of different quinazoline analogues, such as phase-transfer synthesis, ultrasound-promoted synthesis, etc. The gradually improved synthetic methods better the synthetic research on quinazoline derivatives with a tendency of faster, more diverse and more convenient. Then, for another, it is known that substituents at different positions affect the activity differently. For instance, quinazoline derivatives with imidazole substituted at the 2-position of side chain own potent antiinflammatory function; and quinazoline derivatives with amine or substituted amine on 4-position and either halogens or electron rich substituent groups on 6position could promote the anti-cancer and antimicrobial activities $[7,12]$, etc. By careful observation of the recent researches, 2-, 4- and 6-position substituted quinazoline analogs remain majority among the products. However, with the deepening and development of researches, substituent groups at other positions are also achieved and studied increasingly, such as the construction of N-heterocyclic quinazolines by introduction of active groups into 3-position of quinazoline core. It is worth mentioning that $\mathrm{N}$-heterocyclic quinazolines with more rigid and complicated structure were synthesized successively, some of which showed excellent antimicrobial properties. In addition, it could be drawn from the research progress above that enhancement of activity by splicing method of installing various active groups is and will still be the main method for drug design and reconstruction of quinazoline derivatives.
Competing interests

The authors declare that they have no competing interests.

\section{Authors' contributions}

FG and DW have been involved in preparing the manuscript. The two authors are thought to have equal contributions. Both authors have read and approved the final manuscript.

\section{Acknowledgement}

This project was supported by the National Natural Science Foundation of China (No. 81001383) and the Doctoral Foundation of Ministry of Education of China (No. 20105103120009).

Received: 22 February 2013 Accepted: 26 April 2013

Published: 3 June 2013

\section{References}

1. Chandregowda V, Kush AK, Chandrasekara Reddy G: Synthesis and in vitro antitumor activities of novel 4-anilinoquinazoline derivatives. Eur J Med Chem 2009, 44:3046-3055.

2. Al-Rashood ST, Aboldahab IA, Nagi MN, Abouzeid LA, Abdel-Aziz AA, Abdel-Hamide SG, Youssef KM, Al-Obaid AM, El-Subbagh HI: Synthesis, dihydrofolate reductase inhibition, antitumor testing, and molecular modeling study of some new $4(3 \mathrm{H})$-quinazolinone analogs. Bioorg Med Chem 2006, 14:8608-8621.

3. Vasdev N, Dorff PN, Gibbs AR, Nandanan E, Reid LM, Neil JPO', VanBrocklin HF: Synthesis of 6-acrylamido-4-(2-[18F] fluoroanilino) quinazoline: A prospective irreversible EGFR binding probe. J Lablelled Compd Rad 2005, 48:109-115.

4. Wakeling AE, Guy SP, Woodburn JR, Ashton SE, Curry BJ, Barker AJ, Gibson KH: ZD1839 (Iressa): an orally active inhibitor of epidermal growth factor signaling with potential for cancer therapy. Cancer Res 2002, 62:5749-5754.

5. Alagarsamy V, Solomon VR, Dhanabal K: Synthesis and pharmacological evaluation of some 3-phenyl-2-substituted-3H -quinazolin-4-one as analgesic, anti-inflammatory agents. Bioorg Med Chem 2007, 15:235-241.

6. Baba A, Kawamura N, Makino H, Ohta Y, Taketomi S, Sohda T: Studies on disease-modifying antirheumatic drugs: synthesis of novel quinoline and quinazoline derivatives and their anti-inflammatory effect1. J Med Chem 1996, 39:5176-5182

7. Rohini R, Muralidhar Reddy P, Shanker K, Hu A, Ravinder V: Antimicrobial study of newly synthesized 6-substituted indolo[1,2-c]quinazolines. Eur J Med Chem 2010, 45:1200-1205

8. Antipenko L, Karpenko A, Kovalenko S, Katsev A, Komarovska-Porokhnyavets E, Novikov V, Chekotilo A: Synthesis of new 2-thio-[1,2,4]triazolo[1,5-c] quinazoline derivatives and its antimicrobial activity. Chem Pharm Bull 2009, 57:580-585.

9. Jatav $V$, Kashaw S, Mishra P: Synthesis and antimicrobial activity of some new 3-[5-(4-substituted)phenyl-1,3,4-oxadiazole-2yl]-2-styrylquinazoline4(3H)-ones. Med Chem Res 2008, 17:205-211.

10. Aly AA: Synthesis of novel quinazoline derivatives as antimicrobial agents. Chin J Chem 2003, 21:339-346.

11. Li H, Huang R, Qiu D, Yang Z, Liu X, Ma J, Ma Z: Synthesis and bioactivity of 4-quinazoline oxime ethers. Prog Nat Sci 1998, 8:359-365.

12. Chandrika PM, Yakaiah T, Narsaiah B, Sridhar V, Venugopal G, Rao JV, Kumar KP, Murthy USN, Rao ARR: Synthesis leading to novel 2,4,6-trisubstituted quinazoline derivatives, their antibacterial and cytotoxic activity against THP-1, HL-60 and A375 cell lines. Indian J Chem 2009, 48B:840-847.

13. Paneersalvam $P$, Raj T, Ishar PS M, Singh B, Sharma V, Rather BA: Anticonvulsant activity of Schiff bases of 3-amino-6,8-dibromo-2-phenylquinazolin-4(3H)-ones. Indian J Pharm Sci 2010, 72:375-378.

14. Nandy P, Vishalakshi MT, Bhat AR: Synthesis and antitubercular activity of Mannich bases of 2-methyl-3H-quinazolin-4-ones. Indian J Heterocyd Chem 2006, 15:293-294.

15. Saravanan G, Alagarsamy V, Prakash CR: Synthesis and evaluation of antioxidant activities of novel quinazoline derivatives. Int J Pharm Pharm Sci 2010, 2:83-86.

16. Lakhan $R$, Singh OP, Singh-J RL: Studies on $4(3 \mathrm{H})$-quinazolinone derivatives as anti-malarials. J Indian Chem Soc 1987, 64:316-318.

17. Hess HJ, Cronin TH, Scriabine A: Antihypertensive 2-amino-4(3H)quinazolinones. J Med Chem 1968, 11:130-136. 
18. Sasmal S, Balaji G, Kanna Reddy HR, Balasubrahmanyam D, Srinivas G, Kyasa S, Sasmal PK, Khanna I, Talwar R, Suresh J, Jadhav VP, Muzeeb S, Shashikumar D, Harinder Reddy K, Sebastian VJ, Frimurer TM, Rist Ø, Elster L, Högberg T: Design and optimization of quinazoline derivatives as melanin concentrating hormone receptor 1 (MCHR1) antagonists. Bioorg Med Chem Lett 2012, 22:3157-3162.

19. Alvarado M, Barceló M, Carro L, Masaguer CF, Raviña E: Synthesis and biological evaluation of new quinazoline and cinnoline derivatives as potential atypical antipsychotics. Chem Biodivers 2006, 3:106-117.

20. Malamas MS, Millen J: Quinazolineacetic acids and related analogs as aldose reductase inhibitors. J Med Chem 1991, 34:1492-1503.

21. Povarov LS: $a, \beta$-Unsaturated ethers and their analogues in reactions of diene synthesis. Russ Chem Rev 1967, 36:656-669.

22. Reymond S, Cossy J: Copper-catalyzed Diels-alder reactions. Chem Rev 2008, 108:5359-5406.

23. Chen $X$, Wei $H$, Yin L, Li X: A convenient synthesis of quinazoline derivatives via cascade imimo-Diels-Alder and oxidation reaction. Chin Chem Lett 2010, 21:782-786.

24. Molina P, Vilaplana MJ: Iminophosphoranes: useful building blocks for the preparation of nitrogen-containing heterocycles. Synthesis 1994, 1994:1197-1218.

25. He P, Nie YB, Wu J, Ding MW: Unexpected synthesis of indolo[1,2-c] quinazolines by a sequential ugi 4CC-Staudinger-aza-Wittig-nucleophilic addition reaction. Org Biomol Chem 2011, 9:1429-1436.

26. Ding MW, Yang SJ, Chen YF: Synthesis and fungicidal activities of 2-alkoxy-3Hquinazolin-4-ones. Chin J Org Chem 2004, 24:923-026.

27. Barthelemy S, Schneider S, Bannwarth W: Parallel fluorous biphasic synthesis of $3 \mathrm{H}$-quinazolin-4-ones by an Aza-Wittig reaction employing perfluoroalkyl-tagged triphenylphosphine. Tetrahedron Lett 2002, 43:807-810

28. Mavandadi F, Lidstrom P: Microwave- assisted chemistry in drug discovery. Curr Top Med Chem 2004, 4:773-792.

29. Gedye R, Smith F, Westaway K, Ali H, Baldisera L: The use of microwave ovens for rapid organic synthesis. Tetrahedron Lett 1986, 27:279-282.

30. Liu YP, Yin DC, Chen HT, Sun BG: Rapid synthesis of flavor compound 4-ethyloctanoic acid under microwave irradiation. Int J Mol Sci 2010, 11:4165-4174

31. Cleophax J, Liagre M, Loupy A, Petit A: Application of focused microwaves to the scale-up of solvent-free organic reactions. Org Process Res Dev 2000, 4:498-504.

32. Luo H, Hu D, Wu J, He M, Jin L, Yang S, Song B: Rapid synthesis and antiviral activity of (quinazolin-4-ylamino)methyl-phosphonates through microwave irradiation. Int J Mol Sci 2012, 13:6730-6746.

33. Tu S, Li C, Li G, Cao L, Shao Q, Zhou D, Jiang B, Zhou J, Xia M: Microwaveassisted combinatorial synthesis of polysubstituent imidazo[1,2-a] quinoline, pyrimido[1,2-a]quinoline and quinolino[1,2-a]quinazoline derivatives. J Comb Chem 2007, 9:1144-1148.

34. Kidwai M, Saxena S, Khalilur Rahman Khan M, Thukral SS: Synthesis of 4-aryl-7, 7-dimethyl-1,2,3,4,5,6,7,8-octahydroquinazoline-2-one/thione-5-one derivatives and evaluation as antibacterials. Eur J Med Chem 2005, 40:816-819.

35. Hazarkhani H, Karimi B: A facile synthesis of new 3-(2-benzimidazolyl)-2alkyl-4-(3H)-quinazolinones under microwave irradiation. Tetrahedron 2003, 59:4757-4760.

36. Qiu G, He Y, Wu J: Preparation of quinazolino[3,2-a]quinazolines via a palladium-catalyzed three-component reaction of carbodiimide, isocyanide, and amine. Chem Commun 2012, 48:3836-3838.

37. McGowan MA, McAvoy CZ, Buchwald SL: Palladium-catalyzed $\mathrm{N}$-monoarylation of amidines and a one-pot synthesis of quinazoline derivatives. Org Lett 2012, 14:3800-3803.

38. Shi DQ, Rong SF, Dou GL, Wang MM: One-pot synthesis of imidazo[1,2-c] quinazoline derivatives from nitro-componds reduced by Zinc. J Heterocyclic Chem 2009, 46:971-974.

39. MCMurry JE, Fleming MP: Prepared from o-anisaldehyde. J Am Chem Soc 1974, 96:4708-4709.

40. Shi DQ, Shi CL, Wang JX, Rong LC, Zhuang QY, Wang XS: An efficient synthesis of quinazoline derivatives with the aid of low-valent Titanium reagent. J Heterocyclic Chem 2005, 42:173-183.

41. Sang P, Xie YJ, Zou JW, Zhang YH: Copper-catalyzed sequential Ullmann $\mathrm{N}$-arylation and aerobic oxidative $\mathrm{C}-\mathrm{H}$ amination: a convenient route to indolo[1,2-c]quinazoline derivatives. Org Lett 2012, 14:3894-3897.
42. Jiang M, Li J, Wang F, Zhao YC, Zhao F, Dong XC, Zhao WL: A facile Copper-catalyzed one-pot domino synthesis of 5,12-dihydroindolo[2,1-b] quinazolines. Org Lett 2012, 14:1420-1423.

43. Kundu NG, Gopeswar C: Copper-catalysed heteroannulation with alkynes: a general and highly regio- and stereoselective method for the systhesis of (E)-2-(2-arylvinyl) quinazolines. Tetrahedron 2001, 57:6833-6842.

44. Bischler A, Barad D: Zur Kenntniss der pheomiazinderivte. Berichte 1892, 25:3080-3097.

45. Schofield K, Swain T, Theobald RS: The preparation of some a $\omega$-diquinazolinylalkanes. J Chem Soc 1952:1924-1926.

46. Ferrini S, Ponticelli F, Taddei M: Convenient synthetic approach to 2,4-disubstituted quinazolines. Org Lett 2007, 9:69-72.

47. Schofield K: Miscellaneous quinazoline derivatives. J Chem Soc 1954:4034-4035.

48. Zhang L, Gao Z, Peng C, Bin ZY, Zhao D, Wu J, Xu Q, Li JX: Ultrasoundpromoted synthesis and immunosuppressive activity of novel quinazoline derivatives. Mol Divers 2012, 16:579-590.

49. Dehmlow EV, Dehmlow SS: Phase Transfer Catalysis. New York: VCH Publisher; 1993:12.

50. Stark CM, Liotta C, Halpern M: Phase Transfer Catalysis, Fundamentals, Application and Industrial Perspectives.. New York: Chapman \& Hall; 1994:25.

51. Sasson Y, Neumann R: Handbook of Phase Transfer Catalysis. New York: Chapman \& Hall; 1997:126.

52. Khalil AK: Phase-transfer catalyzed alkylation and cycloalkylation of 2-mercaptoquinazolin-4(3H)-one. Phosphorus Sulfur 2005, 180:2533-2541.

53. Ma Y, Liu F, Yan K, Song BA, Yang S, Hu DY, Jin LH, Xue W: Synthesis and antifungal bioactivity of 6-bromo-4-alkylthio-quinazoline derivatives. Chin J Org Chem 2008, 28:1268-1272.

54. Rohini R, Shanker K, Reddy PM, Ho YP, Ravinder V: Mono and bis-6arylbenzimidazo[1,2-c]quinazolines: $\mathrm{A}$ new class of antimicrobial agents. Eur J Med Chem 2009, 44:3330-3339.

55. Pandey SK, Singh A, Singh A, Nizamuddin: Antimicrobial studies of some novel quinazolinones fused with $[1,2,4]$-triazole, $[1,2,4]$-triazine and [1,2,4,5]-tetrazine rings. Eur J Med Chem 2009, 44:1188-1197.

56. Zhang G, Liang YQ, Zhang RL, Zhang WH, Zhao JS, Guo ZA: Synthesis and Crystal Structure of a New Quinazolinone compound 2,3-dihydro-2-(2hydroxyphenyl)-3-phenyl-quinazolin-4(1H)-one. Chinese J Struct Chem 2005, 24:783-788.

57. Kanuma K, Omodera K, Nishiguchi M, Funakoshi T, Chaki S, Nagase Y, lida I, Yamaguchi J, Semple G, Tran TA, Sekiquchi Y: Identification of 4-amino-2cyclohexylaminoquinazolines as metabolically stable melaninconcentrating hormone receptor 1 antagonists. Bioorg Med Chem 2006, 14:3307-3319.

58. Kanuma K, Omodera K, Nishiguchi M, Funakoshi T, Chaki S, Semple G, Tran TA, Kramer B, Hsu D, Casper M, Thomsen B, Sekiguchi Y: Lead optimization of 4-(dimethylamino)quinazolines, potent and selective antagonists for the melanin-concentrating hormone receptor 1. Bioorg Med Chem Lett 2005, 15:3853-3856

59. Chaki S, Funakoshi T, Hirota-Okuno S, Nishiguchi M, Shimazaki T, lijima M, Grottick AJ, Kanuma K, Omodera K, Sekiguchi Y, Okuyama S, Tran TA, Semple G, Thomsen W: Anxiolytic- and antidepressant-like profile of ATC0065 and ATC0175: Nonpeptidic and orally active melanin-concentrating hormone receptor 1 antagonists. J Pharmacol Exp Ther 2005, 313:831-839.

60. Fry DW, Kraker AJ, McMichael A, Ambroso LA, Nelson JM, Leopold WR, Connors RW, Bridges AJ: A specific inhibitor of the epidermal growth factor receptor tyrosine kinase. Science 1994, 265:1093-1095.

61. Rewcastle GW, Denny WA, Bridges AJ, Zhou H, Cody DR, McMichael A, Fry DW: Tyrosine kinase inhibitors. 5. Synthesis and structure-activity relationships for 4-[(phenyl-methyl)amino]- and 4-(phenylamino)quinazolines as potent adenosine-5'-triphosphate binding site inhibitors of the tyrosine kinase domain of the epidermal growth factor receptor. J Med Chem 1995, 38:3482-3487.

62. Barker AJ: Quinazoline derivatives. Eur Patent App/ 1993:0566226A1.

63. Ward WHJ, Cook PN, Slater AM, Davies DH, Holdgate GA, Green LR: Epidermal growth factor receptor tyrosine kinase. Investigation of catalytic mechanism, structure-based searching and discovery of a potent inhibitor. Biochem Pharmacol 1994, 48:659-666.

64. Bridges AJ, Zhou H, Cody DR, Rewcastle GW, Mc-Michael A, Showalter HDH, Fry DW, Kraker AJ, Denny WA: Tyrosine kinase inhibitors. 8. An unusually steep structure activity relationship for analogues of 4-(3-bromo-anilino)6,7-dimethoxyqinazoline (PD 153035), a potent inhibitor of the epidermal growth factor receptor. J Med Chem 1996, 39:267-276. 
65. Bridjes AJ: Chemical inhibitors of protein kinases. Chem Rev 2001, 101:2541-2571.

66. Klutchko SR, Zhou H, Winters RT, Tran TP, Bridges AJ, Althaus IW Amato DM, Elliott WL, Ellis PA, Meade MA, Roberts BJ, Fry DW Gonzales AJ, Harvey PJ, Nelson JM, Sherwood V, Han HK, Pace G, Smaill JB, Denny WA, Showalter HD: Tyrosine kinase inhibitors. 19. 6-alkynamides of 4-anilinoquinazolines and 4-anilinopyrido[3,4-d] pyrimidines as irreversible inhibitors of the erbB family of tyrosine kinase receptors. J Med Chem 2006, 49:1475-1485.

67. Hickey K, Grehan D, Reid IM: Expression of epidermal growth factor receptor and proliferating cell nuclear antigen pre-dicts response of esophageal squamous cell carcinoma to chemora-diotherapy. Cancer 1994, 74:1693-1698.

68. Lü S, Zheng W, Ji L, Luo Q, Hao X, Li X, Wang F: Synthesis, characterization, screening and docking analysis of 4-anilinoquinazoline derivatives as tyrosine kinase inhibitors. Eur J Med Chem 2013, 61:84-89.

69. Hu S, Xie G, Zhang DX, Davis C, Long W, Hu Y, Wang F, Kang X, Tan F, Ding L, Wang Y: Synthesis and biological evaluation of crown ether fused quinazoline analogues as potent EGFR inhibitors. Bioorg Med Chem Lett 2012, 22:6301-6305.

70. Fry DW, Bridges AJ, Denny WA, Doherty A, Greis KD, Hicks JL, Hook KE, Keller PR, Leopold WR, Loo JA, McNamara DJ, Nelson JM, Sherwood V, Smaill JB, Trumpp-Kallmeyer S, Dobrusin EM: Specific, irreversible inactivation of the epidermal growth factor receptor and erbB2, by a new class of tyrosine kinase inhibitor. Proc Nat Acad Sci USA 1998, 95:12022-12027.

71. Smaill JB, Palmer BD, Rewcastle GW, Denny WA, McNamara DJ, Dobrusin EM, Bridges AJ, Zhou H, Schowalter HDH, Winters RT, Leopold WR, Fry DW, Nelson JM, Slintak V, Elliot WL, Roberts BJ, Vincent PW, Patmore SJ: Tyrosine kinase inhibitors. 15. 4-(phenylamino)quinazoline and 4(phenylamino)pyrido[d]pyrimidine acrylamides as irreversible inhibitors of the ATP binding site of the epidermal growth factor receptor. J Med Chem 1999, 42:1803-1815.

72. Nandi AK, Chaudhri S, Mazumdah SK, Gosh S: Effect of chlorine substitution on the structure and activity of 4-phenylthiosemicarbazide: crystal and molecular structure of 4-(4-chlorophenyl) thiosemicarbazide. J Chem Soc Perkin Trans 1984, 2:1729-1733.

73. Ali MA, Chowdhary DA, Naziruddin M: Four- and five-coordinatecopper(II) complexes containing mixed ligands. Polyhedron 1984, 3:595-598.

74. Scovill JP, Klayman DL, Franchino CF: 2-Acetylpyridine thiosemicarbazones. 4. Complexes with transition metals as antimalarial and antileukemic agents. J Med Chem 1982, 25:1261-1264.

75. He JB, Wang XG, Zhao XQ, Liang YJ, He HW, Fu LW: Synthesis and antitumor activity of novel quinazoline derivatives containing thiosemicarbazide moiety. Eur J Med Chem 2012, 54:925-930.

76. Bonner JC, Lindroos PM, Rice AB, Moomaw CR, Morgan DL: Induction of PDGF receptor-alpha in rat myofi-broblasts during pulmonary fibrogenesis in vivo. Am J Physiol 1998, 274:72-80.

77. Friedman SL: Molecular regulation of hepatic fibrosis, an integrated cellular response to tissue injury. J Biol Chem 2000, 275:2247-2250.

78. Gesualdo L, Pinzani M, Floriano JJ, Hassan MO, Nagy NU, Schena FP, Emancipator SN, Abboud HE: Platelet-derived growth factor expression in mesangial proliferative glomerulonephritis. Lab Invest 1991, 65:160-167.

79. Heldin $\mathrm{CH}$, Westermark B: Platelet-derived growth factor: mechanism of action and possible in vivo function. Cell Regul 1990, 1:555-566.

80. lida $H$, Seifert $R$, Alpers CE, Gronwald RG, Phillips PE, Pritzl P, Gordon K, Gown AM, Ross R, Bowen-Pope DF, et al: Platelet-derived growth factor (PDGF) and PDGF receptor are induced in mesangial proliferative nephritis in the rat. Proc Natl Acad Sci USA 1991, 88:6560-6564.

81. Johnson RJ, Raines EW, Floege J, Yoshimura A, Pritzl P, Alpers C, Ross R: Inhibition of mesangial cell proliferation and matrix expansion in glomerulonephritis in the rat by antibody to platelet-derived growth factor. J Exp Med 1992, 175:1413-1416.

82. Rice AB, Moomaw CR, Morgan DL, Bonner JC: Specific inhibitors of platelet-derived growth factor or epidermal growth factor receptor tyrosine kinase reduce pulmonary fibrosis in rats. Am J Pathol 1999, 155:213-221.

83. Ross R, Masuda J, Raines EW, Gown AM, Katsuda S, Sasahara M, Malden LT, Masuko $\mathrm{H}$, Sato $\mathrm{H}$ : Localization of PDGF-B protein in macrophages in all phases of atherogen-esis. Science 1990, 248:1009-1012.
84. Wilcox JN, Smith KM, Williams LT, Schwartz SM, Gordon D: Platelet-derived growth factor mRNA detection in human atherosclerotic plaques by in situ hybridization. J Clin Invest 1988, 82:1134-1143.

85. Wong L, Yamasaki G, Johnson RJ, Friedman SL: Induction of beta-platelet -derived growth factor receptor in rat hepatic lipocytes during cellular activation in vivo and in culture. J Clin Invest 1994, 94:1563-1569.

86. Yagi M, Kato S, Kobayashi Y, Kobayashi N, linuma N, Nakamura K, Kubo K, Ohyama S, Murooka H, Shimizu T, Nishitoba T, Osawa T, Nagano N: Beneficial effects of a novel inhibitor of platelet-derived growth factor receptor auto-phosphorylation in the rat with mesangial proliferative glom-erulonephritis. Gen Pharmacol 1998, 31:765-773.

87. Matsuno K, Ichimura M, Nakajima T, Tahara K, Fujiwara S, Kase H, Ushiki J, Giese NA, Pandey A, Scarborough RM, Lokker NA, Yu JC, Irie J, Tsukuda E, Ide S, Oda S, Nomoto Y: Potent and selective inhibitors of platelet-derived growth factor receptor phosphorylation. 1. synthesis, structure-activity relationship, and biological effects of a new class of quinazoline derivatives. J Med Chem 2002, 45:3057-3066.

88. Rewcastle GW, Palmer BD, Bridges AJ, Showalter HDH, Sun L, Nelson J, McMichael A, Kraker AJ, Fry DW, Denny WA: Tyrosine kinase inhibitors. 9. synthesis and evaluation of fused tricyclic quinazoline analogues as ATP site inhibitors of the tyrosine kinase activity of the epidermal growth factor receptor. J Med Chem 1996, 39:918-928.

89. Jantova S, Ovadekova R, Letasiova S, Spirkova K, Stankovsky S: Antimicrobial activity of some substituted triazoloquinazolines. Folia Microbiol 2005, 50:90-94.

90. Nasr MN, Gineinah MM, El-Bendary ER: Synthesis and in vitro antibacterial evaluation of novel imidazo[2', $\left.1^{\prime}: 5,1\right]-1,2,4$-triazolo[4,3-c]-quinazoline derivatives of 5-thioxo-1, 2, 4-triazole, 4-oxothiazolidine, and their open-chain counterparts. Arch Pharm 2003, 336:560-566.

91. Ibrahim SS, Abdel-Halim AM, Gabr Y, El-Edfawy S, Abdel-Rahman RM: Synthesis and biological evaluation of some new fused quinazoline derivatives. J Chem Res 1997, 5:1041-1063.

92. El-Sayed R, Wasfy AF: Synthesis of heterocycle having double characters as antimicrobial and surface active agents. J Chin Chem Soc 2005, 52:129-135.

93. El-Sayed R, Wasfy AAF, Aly AA: Synthesis of novel heterocycles with antimicrobial and surface activity. J Heterocycl Chem 2005, 42:125-130.

94. Bhalla M, Srivastava VK, Bhalla TN, Shanker K: Anti-inflammatory and analgesic activity of indolyl quinazolones and their congeners. Arzneimittelforschung 1993, 43:595-600.

95. Hitkari A, Saxena M, Verma AK, Gupta M, Shankar MP: Substituted quinazolinones and their anti-inflammatory activity. Bull Chim Farm 1995, 134:609-615.

96. Alagarsamy V, Solomon VR, Vanikavitha G, Paluchamy V, Ravichandran M, Sujin AA, Thanga-thirupathy A, Amuthalakshmi S, Revathi R: Synthesis, analgesic, anti-inflammatory and antibacterial activities of some novel 2-phenyl-3-substituted quinazolin-4(3H)-ones. Biol Pharm Bull 2002, 25:1432-1435.

97. Alagarsamy V, Murugananthan G, Venkateshperumal R: Synthesis, analgesic, anti-inflammatory and antibacterial activities of some novel 2-methyl-3substituted quinazolin-4-(3H)-ones. Biol Pharm Bull 2003, 26:1711-1714

98. Alagarsamy V, Rajesh R, Meena R, Vijaykumar S, Ramseshu KV, Anandakumar TD: Synthesis, analgesic, anti-inflammatory and antibacterial activities of some novel 2-methylthio-3-substituted quinazolin-4-(3H)-ones. Biol Pharm Bull 2004, 27:652-656.

99. Alagarsamy V, Muthukumar V, Pavalarani N, Vasan-thanathan P, Revathi R: Synthesis, analgesic and anti-inflammatory activities of some novel 2,3-disubstituted quinazolin-4(3H)-ones. Biol Pharm Bull 2003, 26:557-559.

100. Bhati SK, Kumar A: Synthesis of new substituted azetidinoyl and thiazolidinoyl-1,3,4-thiadiazino(6,5-b)indoles as promising anti-inflammatory agents. J Med Chem 2008, 43:2323-2330.

101. Sonar VN, Yazadan SK, Sreenivasulu N: Synthesis of oxadiazolylindole derivatives and their anti-inflammatory activity. Indian J Heterocycl Chem 2001, 19:299-302

102. Wincent E, Shirani H, Bergman J, Rannug U, Janosik T: Synthesis and biological evaluation of fused thio- and selenopyrans as new indolocarbazole analogues with aryl hydrocarbon receptor affinity. Bioorg Med Chem 2009, 17:1648-1653.

103. Sinha D, Tiwari AK, Singh S, Shukl G, Mishra P, Chandra H, Mishra AK: Synthesis, characterization and biological activity of Schiff base analogues of indole-3-carboxaldehyde. J Med Chem 2008, 43:160-165. 
104. Bhattacharjee AK, Hartell MG, Nichols DA, Hicks RP, Stanton B, Hamont JE, Milhous WK: Structure-activity relationship study of antimalarial indolo [2,1-b]quinazoline-6,12-diones (tryptanthrins). Three dimensional pharmacophore modeling and identification of new antimalarial candidates. J Med Chem 2004, 39:59-67.

105. Prudhomme M: Rebeccamycin analogues as anti-cancer agents. J Med Chem 2003, 38:123-140.

106. He L, Chang H, Chou TC, Savaraj N, Cheng CC: Design of antineoplastic agents based on the '2-phenylnaphthalene-type' structural patternsynthesis and biological activity studies of $11 \mathrm{H}$-indolo[3.2-c]quinoline derivatives. J Med Chem 2003, 38:101-107.

doi:10.1186/1752-153X-7-95

Cite this article as: Wang and Gao: Quinazoline derivatives: synthesis

and bioactivities. Chemistry Central Journal 2013 7:95.

\section{Publish with ChemistryCentral and every scientist can read your work free of charge}

"Open access provides opportunities to our colleagues in other parts of the globe, by allowing anyone to view the content free of charge."

W. Jeffery Hurst, The Hershey Company.

- available free of charge to the entire scientific community

- peer reviewed and published immediately upon acceptance

- cited in PubMed and archived on PubMed Central

- yours - you keep the copyright

Submit your manuscript here:

http://www.chemistrycentral.com/manuscript/<smiles>c1ccccc1</smiles> 